\title{
The Twin Effects of Globalization \\ Evidence from a Sample of Indian Manufacturing Firms
}

\author{
Francesco Daveri \\ Paolo Manasse \\ Danila Serra
}

CESIFO WORKING PAPER NO. 3174

CATEgOry 8: TRAdE POLICY

SEPTEMBER 2010

\footnotetext{
An electronic version of the paper may be downloaded

- from the SSRN website: Www.SSRN.com

- from the RePEc website: $\quad$ www.RePEc.org

- from the CESifo website: $\quad$ www.CESifo-group.org/wp
} 


\title{
The Twin Effects of Globalization Evidence from a Sample of Indian Manufacturing Firms
}

\begin{abstract}
Employees of globalized firms face a riskier menu of labor market outcomes. They face a more uncertain stream of earnings and riskier employment prospects. However, they may also have stronger incentives to train and upgrade their skills and/or may benefit from more rapid careers. Hence, the costs of uncertainty and the benefits of skill upgrading associated with globalization may be twin to each other. We provide statistical evidence of this so far neglected trade-off for a sample of Indian manufacturing firms.
\end{abstract}

JEL-Code: F10, F16, J30, J31, O53.

Keywords: globalization, uncertainty, training, labor markets, India.

Francesco Daveri

University of Parma

Department of Economics

Via Kennedy 6

Italy-43100 Parma

francesco.daveri@unipr.it

\author{
Paolo Manasse \\ University of Bologna \\ Department of Economics \\ paolo.manasse@unibo.it
}

\author{
Danila Serra \\ Florida State University \\ Department of Economics \\ dserra@fsu.edu
}

September 2, 2010

This paper was part of the joint Luca d'Agliano-World Bank project "Trade, technology diffusion and performance in Indian manufacturing". Earlier drafts of this paper benefited from the useful comments of Giorgio Barba Navaretti, Paolo Epifani, Eliana La Ferrara, Dani Rodrik, Olmo Silva and two anonymous referees of this journal. We are also thankful to seminar participants at Bocconi, the State University of Milan and Parma, ETLA (Helsinki) and to the participants in a CEPR Workshop on "Trade, Industrialization and Development" at the Centre for Economic Performance, London. Guido Tabellini provided useful suggestions at an early stage of this project. 


\section{INTRODUCTION}

Critics of globalization argue that openness undermines labor market institutions by lowering job security and raising the volatility of real incomes. In this paper we argue that this is only a partial view of the effects of globalization on the labor market. In our sample of Indian manufacturing firms, we find that the employees of "globalized" firms face a riskier but also more rewarding menu of labor market outcomes. On the one hand, the employees of firms subject to foreign competition indeed face more volatility in their earning streams and employment prospects. At the same time, however, their ability to upgrade their skills is higher (they are more likely to be involved in training programs) and/or their career is faster (they are more likely to be promoted). This holds in a multivariate framework after controlling for the productivity differences that may induce the best performing firms to selfselect into becoming global. Thus we conclude that, with globalization, the costs of uncertainty are associated with the benefits of skill upgrading: isolating one side of the coin gives a misleading picture of globalization.

The labor market effects of trade liberalization in developing countries have been extensively investigated in the literature. Among the beneficial effects, the Stolper-Samuelson theorem suggests that wage inequality should fall when countries which are relatively abundant of unskilled labor open to trade. Most models of imperfect competition suggest that, as market size grows, workers should benefit from higher real wages and more employment opportunities. Moreover, there is evidence that trade integration raises growth via technology transfers, knowledge spillovers and scale economies. ${ }^{1}$

These implications are controversial, though. The presumption that globalization brings about a fall in wage inequality only holds as long as developing countries, before opening up their economies, do not levy high tariffs on labor-intensive industries. If this is the case, factor intensities may be reversed and globalization may thus widen, rather than narrow, wage inequality. Moreover, the causal link between exporting activity and productivity growth has also been questioned, and the alleged causal relationship among them has been object of extensive theoretical and empirical scrutiny. ${ }^{2,3}$

\footnotetext{
${ }^{1}$ Bernard and Jensen (1997) find a significant positive relation between exports and productivity, the "learningby-exporting effect".

${ }^{2}$ Bernard and Jensen (1999) and Clerides, Lach and Tybout (1998) first pointed out that the positive correlation between exports and productivity, rather than reflecting the beneficial consequence of integration, is the result of the firms' self-selection: only the most productive firms become exporters.
} 
On the other hand, the list of the risks typically associated with globalization is quite long. Rodrik (1997) and Stiglitz (2002) have emphasized the potential for domestic labor market disruption and the trade-off between static and dynamic gains from trade, when comparative advantage locks developing countries in low-growth sectors. Rodrik has also argued that globalization is likely to raise labor market volatility, since firms may more easily substitute foreign for domestic labor and consumers may more easily substitute foreign for domestic goods. As a result, the firms' demand for labor becomes more elastic, so that demand shocks have magnified effects on wages and employment. Yet whether international integration and uncertainty are empirically related is a matter which is hardly settled in empirical work Rodrik (1998) finds that exposure to international risk, measured by the interaction between trade openness and terms of trade volatility, is associated with growth volatility and the size of government. In contrast, Iversen and Cusak (2000) find no significant relationship between, on one hand, the volatility of output, employment and wages in OECD countries, and, on the other, trade; Slaughter (2001) presents evidence for the US economy showing that the wage elasticity of labor demand has increased for production workers but not for non-production workers.

Our paper adds to this literature by focusing on a less explored aspect of the opennessvolatility relationship. In a sample of Indian manufacturing firms in the late 1990s, we document that firms (and workers) exposed to globalization react to the uncertainty associated to foreign competition by investing more in training. We also find evidence that the employees of global firms on average have faster careers. More precisely, firms that are more exposed to international competition in our sample: 1) display a higher volatility of sales, profits, employment and prices; 2) are more likely to train and promote their employees. This is particularly apparent for exporters compared to non-exporters. This finding also applies, albeit less robustly, to firms that face import competition in the domestic market and is robust to changes in the empirical specification. These results to our knowledge are novel in the literature.

The paper is structured as follows. Section 2 discusses the effects of uncertainty on labor market outcomes. Section 3 discusses the reasons why India in the late 1990s is an interesting case-study for the effects of globalization on firms. Section 4 describes the data set and compares the levels and volatility of wages, employment, prices, sales, profits, promotions

\footnotetext{
${ }^{3}$ For comprehensive surveys of the effects of globalization on labor markets in developing countries see Hanson and Harrison (1999), Robertson (2000) and Epifani (2003). Brown, Deardorff and Stern (2002) surveyed the evidence on the relation between FDI, wages, working conditions and labor standards.
} 
and training for firms with different degrees of exposure to international competition Section 5 describes our econometric methodology and the results. Section 6 concludes.

\section{CONCEPTUAL FRAMEWORK}

Globalization may raise volatility through different channels. For example, the impact of terms of trade shocks on real wages may be larger the higher the share of imported goods in the consumption basket. Productivity shocks may also be more frequent and larger for firms exposed to international competition, since they face a larger variety of close substitutes produced by foreign competitors. Globalization may also weaken long-term employment relationships (Newman and McLaren, 2002), add to price uncertainty and increase specialization, so that risks become more rather than less concentrated (Iversen and Cusak, 2000). On the other hand, there are many ways in which firms and workers may react to a more volatile environment. Firms may try to develop new products and exploit the (possibly) more stable revenue stream that comes from the monopoly power in the new products. For example, Bernard et al. (2006) show that higher firm-level ability raises a firm's productivity across all products, which induces a positive correlation between a firm intensive (output per product) and extensive (number of products) margins. Trade liberalization fosters productivity growth within and across firms and in aggregate by inducing firms to shed marginally productive products and forcing the lowest-productivity (low-skill labor intensive) firms to exit.

Finally, firms with limited access to the capital market may find it convenient to expand their size (as measured by employment) as a way to shield their income streams from the uncertainty, and, for similar reason their employees may find it convenient to improve their skills,. In the Appendix we present a simple model that provides a few testable implications: ceteris paribus, firms facing higher uncertainty due to foreign competition should be larger, employ relatively more skilled workers, train them relatively more intensively and promote them relatively more frequently

\section{WHY INDIA?}

We investigate the "twin effects" of globalization by focusing on India in the late 1990s. The trade liberalization reforms, initiated in the early 1990s, gradually exposed Indian manufacturing firms to novel opportunities. 
Since independence, India has been characterized by active government intervention aimed at fostering domestic growth through import substitution. Over the years, the economy became riddled with a number of economic distortions: tariffs and import quotas, industryspecific licensing requirements on investment projects beyond certain thresholds, restrictions on FDI flows (particularly those with little technological content).Export subsidies were usually paid against comparative advantage considerations, typically to firms not belonging to traditional labor intensive sectors.

In June 1991, in the wake of a serious balance-of-payment crisis, a newly elected Government initiated a major program of economic reform and trade liberalization with the support of the IMF and the World Bank. The New Industrial Policy (NIP) slashed average tariffs from 80 per cent in 1990 to 37 per cent in 1996. The number of "strategic" sectors reserved to public enterprises was drastically reduced, and the scope for the cumbersome licensing system severely limited. Under the NIP, new legislation allowed for foreign majority participation in domestic shares, at least for "high priority" and export-oriented industries, and technology transfer agreements stopped being a prerequisite for FDI permissions.

Overall, the wave of reforms of the 1990s was a success. Industrial production grew by seven percent per year in 1992-1997. Import growth boomed to 25 percent per year in 199396, a big jump from the 15 percent rate of the previous five years, while exports grew in line with the previous period (also at a yearly rate of 25 percent). All in all, the degree of openness of the Indian economy - the GDP share of imports plus exports - roughly doubled, from 10 percent in the early 1990s to about 20 percent in the mid 1990s. Over the same period the annual growth rate of private investment reached 16.5 percent, up by about two percentage points from the previous five years. GDP growth accelerated as well.

The benefits didn't last long, however. The South-East Asian crisis of 1997-98 and the subsequent deceleration in the growth of world trade substantially slowed down the growth of the Indian economy. After the 1995-96 growth peak, the growth of industrial production, exports and imports fell considerably in the two subsequent years. In turn, the growth slowdown also triggered (and was probably aggravated by) a reform reversal: between 1997 and 1999, new trade restrictions were put in place again in the form of non-tariff barriers and anti-dumping measures. ${ }^{4}$

\footnotetext{
${ }^{4}$ As many as 103 antidumping measures were still active in 2000, compared to 64 in 1999 and 49 in 1998 . The International Monetary Fund (2001) reports that, throughout 1997-2000, there was little change in the average tariffs rates, while the maximum bound rate was reduced from 45 to $35 \%$.
} 
These developments arguably affected firms according to their effective exposure to foreign competition which makes India at the end of the Nineties an interesting case-study for the effects of globalization. Although we cannot properly evaluate the before-and-after of trade reform (we lack time series data for our labor outcome variables), we can compare the response - conditional and unconditional - of globalized firms (those exporting or facing external competition in the domestic market) to that of firms which were largely shielded from foreign competition.

\section{DATA SET AND DEFINITIONS}

Our data set draws on a survey conducted by the Confederation of Indian Industries and the World Bank on almost nine hundreds manufacturing firms from five industries, i.e. garments, textiles, drugs and pharmaceuticals, electronic consumer goods, and electrical white goods (a branch of electrical machinery). These firms are located in the cities of Ahmedabad (State of Gujarat), Bangalore (Karnataka), Calcutta (West Bengal), Chandigarh (Punjab), Chennai (Tamil Nadu), Cochin (Kerala), Delhi (Haryana), Hyderabad (Andhra Pradesh), Kanpur (Uttar Pradesh), Mumbai and Pune (Maharashtra). ${ }^{5}$ As shown in Table 1 and 2, the selected states and localities host a fairly sizable number of firms in at least three of the industries covered by the survey.

Our multivariate analysis is conducted on a cross-section of firms in 1999, for information about some of our variables of interest (training and promotions) is only available for that year. Yet the World Bank data provide information on several firm characteristics for 1997-1999, such as the ownership structure, the levels of investment and type of technology, the relations with suppliers and the government, the firm's location, the volume of trade, the number of products, their prices, the quantity and types of inputs, labor and human resources, assets and liabilities. We will exploit some of the 1997-99 data to compute our volatility indicators as indicated below.

\footnotetext{
${ }^{5}$ As discussed in Dollar, Iarossi and Mengistae (2002), the selection of the states was based on three criteria. The first criterion was that states at all levels of development be represented in the sample. The states of Delhi, Maharashtra, Gujarat, Punjab and West Bengal represent the high-income group. Andhra Pradesh, Karnataka, Kerala and Tamil Nadu are middle-income states. Uttar Pradesh is the only low-income state. The poorest Indian states (such as Orissa, Bihar, Madhya Pradesh, and Rajasthan) are thus under-represented in the sample. Second, the sample includes some states that have enacted pro-worker legislation and some others which have passed pro-business legislation (see Besley and Burgess 2003). Another paper employing this World Bank data set is Barba Navaretti, Galeotti and Tucci (2002).
} 


\section{Defining "globalization"}

The first step for assessing the labor market implications of globalization is to define what we mean by "globalization" for an individual firm. We use two criteria. In order to capture the firms' degree of exposure to foreign competition in the product market, one would ideally estimate the elasticity of substitution between the firm's product and that of domestic and foreign competitors. In the absence of detailed information on domestic and foreign prices and quantities, we proceed as follows. A firm may face foreign competition either on the domestic (if import-competing) or on foreign (if exporting) markets, or both. In the first instance, we label Exporters (E) all the firms whose revenue share from exports be greater than or equal to 30 percent (and non-exporters the remaining ones). Since both exporting and non-exporting firms may also face foreign competition in the Indian domestic market, we further classify as firms subject to foreign competition (FC) those firms which declare in the survey that they face "foreign competitors in the domestic market". 6 Based on this classification, we partition the 555 firms for which trade and foreign competition information is available into four categories: EFC, ENFC, NEFC and NENFC. The "EFC" firms (there are 127 of them) are the exporters subject to foreign competition in the domestic market, the "ENFC" (82) are the exporters declaring not to face foreign competition when they sell in the domestic market, the 150 "NEFC" are the non-exporting firms subject to foreign competition and, finally the 196 "NENFC" are the non-exporting firms declaring that they do not face foreign competition the domestic market. Clearly, EFC and NENFC firms are respectively the most and the least "exposed-to-globalization" firms in our sample.

Globalization also comes about through access to the international capital market. Thus we label as "Foreign Owned" (FO) firms where foreigners hold positive share of capital. This definition has the inconvenient that does not allow us to discriminate between multinational corporations and joint ventures. It turns out, however that only 4 percent of firms are FOs.

As mentioned above, some of our variables of interest, namely training and promotions, and some of our control variables are only available for a subset of firms and for the year 1999, which makes our actual sample size markedly smaller than its notional size and, at times, in an unbalanced way across specifications. These smaller samples may not be fully representative of the complete sample. We have checked that this is not the case by

\footnotetext{
${ }^{6}$ It should be noted that, while the status of "exporter" is objective, the status of "firm subject to foreign competition" is to a large extent subjective, for it relies on the managers' assessment of the presence of foreign competitors.
} 
comparing descriptive statistics for a number of variables for which data are available for the entire sample and its subset. These statistics turn out to be virtually identical.

\section{$\underline{\text { Sectors and locations }}$}

Table 1 presents the distribution of our 555 manufacturing firms, classified by foreign exposure and sector. Table 2 provides information on the firm classification by location and sector.

\section{- INSERT TABLE 1 HERE -}

Table 1 shows that, according to our definitions, the firms of our sample are considerably more internationally integrated in the product than in the capital market. Almost two thirds of them are exposed to foreign competition in the former, either because they are exporters or because they face foreign competition in the domestic market, with slightly more than one third facing any foreign competition. Foreign capital, instead, accounts for only a minor role in firms' capital structure: only four per cent of the 555 firms report foreign participation in their capital.

The sample distribution of firms across the four categories (EFC, ENFC, NEFC and NENFC) is $23 \%, 15 \%, 27 \%$ and $35 \%$, respectively. However, the distribution is quite heterogeneous across different sectors, revealing an interesting pattern In "Textiles" the shares appear very close to the sample average. By contrast, "Garments" and "Electrical White goods" represent opposite polar cases: about 60 percent of firms in the former are exporters, while $95 \%$ of those in Electronics are either $\mathrm{N}$ or IC firms. "Drugs \& Pharmaceuticals" and "Electrical White Goods" are intermediate sectors with below-average shares of exporters and above-average shares of the other types. Finally, FO firms are mostly concentrated in the "Textiles" and "Drugs \& Pharmaceuticals" sectors, where they represent respectively 5 percent and 7.5 percent of firms.

\section{- INSERT TABLE 2 HERE -}

Table 2 cross-tabulates our classification against the geographical location. Urban areas appear specialized into different structure of productions. As expected, Delhi and Mumbai have the largest number of firms, but they differ somewhat in their specialization. About $45 \%$ of Delhi are not subject to foreign competition, while about one half of Mumbai firms are non-exporters facing foreign competition in the domestic market. About two thirds of the firms located in Chennai, Hyderabad and Cochin are exporters, partly facing foreign competition in the domestic market (EFC) and partly shielded from that (ENFC). Bangalore, 
the preferred location for the software industry, is the most "globalized" city, with more than four fifth of its firms either in the E or the FC group, while the firms in Kanpur and Pune are mainly non-exposed to foreign competition. Finally, most FO firms are located in Delhi (7 percent of the total), but it is in Bangalore, Cochin and Chandigarh where they represent the largest share of local firms (respectively 8 percent, 18 percent and 18 percent). No foreign owned firms on the sample are located in Ahmedabad and Kanpur.

This pattern is consistent with the findings in Sachs, Bajpai and Ramiah (2002), who find that access to the sea is an important determinant of the export status of an Indian firm. The cities of Chennai, Hyderabad, Cochin, Bangalore - all located in Southern states - are close to the seas or have easy access to the sea. Delhi and Kanpur are instead in landlocked. Pune, in the region of Maharashstra, is rather far from the Ocean, and accordingly feature few exporters. Finally, Calcutta and Mumbai are on the Ocean, but cover so large metropolitan areas, that it is not surprising that they also host many non-global firms.

\section{Labor market variables}

Next we compare firms classes along their characteristics in the labor market. The questionnaire provides information on employment, hours worked and wages for five categories of workers (non-production workers, unskilled production workers, skilled production workers, professionals and managers). We aggregate the first three groups into "blue collars", and the last two into "white collars". Absolute and relative wage and employment data are only available for a subset of the 555 firms (respectively, 239 for wages and 509 for employment).

\section{- INSERT TABLE 3 HERE -}

The upper panel of Table 3 reports firm group averages for absolute and relative wages and employment levels as well as for unionization, training and promotion rates. The lower panel of Table 3 reports the p-values of pair-wise tests for equality-of-means between the different firm categories and the control groups of "protected" firms (NENFC) and domestically owned (DO).

The average firm in our sample is quite large (191 workers) - a reflection of the sample's under-representation of small and medium-sized enterprises. As expected, we find that firms not subject to foreign competition are on average much smaller and less unionized than other firms (differences in unionization rates and employment are highly significantly correlated, at the $1 \%$ level). By contrast, the composition of the labor force and the relative and absolute 
wages of white and blue collars are quite similar across categories, with the only exception of foreign owned firms, which are larger and more unionized than domestically owned firms and pay lower white collar salaries - both in absolute and relative terms.

In summary, globalization does not appear to be associated with significant differences in absolute or relative wages, but it seems associated with larger size and higher unionization rates. This finding is consistent with the evidence on Mexico and Morocco presented by Hanson and Harrison (1999).

Another interesting piece of evidence concerns the employees' involvement in formal training programs (either in-house or external to the firm) in 1999. The seventh column of Table 3 shows that the proportion of employees involved in training programs is significantly higher in exportingfirms and firms subject to competition in the domestic market than for NENFC firms. Even more strikingly, as many as 77 percent of employees of foreign owned firms are reported involved in active training programs, while the percentage in DO firms is only 19 percent.

Finally, the last column of Table 3 shows the frequency of promotions, the average share of employees promoted in 1999, for our classification. Strikingly, an employee of an EFC firm is on average three times more likely to be promoted in 1999 than an employee of a NENFC firm. This implies the typical EFC firm employee, while earning a similar wage of a NENFC firm, enjoys in expected terms a noticeably higher lifetime income. Promotion rates are instead similar for non-exporting firms subject (NEFC) and not subject (NENFC) to foreign competition as well as for foreign and domestically owned firms.

\section{$\underline{\text { Volatility }}$}

Next we document that firms subject to foreign competition, abroad or domestically, face a higher volatility of labor and product market outcomes, both in terms of dispersion across firms and in terms of volatility over time. We measure the volatility in the labor and product market by the variance of wages, employment, prices, profits and sales. We construct the firms' output price variable as a geometric mean of the prices of the three main products sold by each firm in each year, using the products' shares in sales as weights. Net profits are defined as the before-tax operating surpluses net of interest charges, depreciation and other overhead expenses.

In order to identify the volatility measure that is more likely to be affected by globalization, we employ a methodology suggested by Gottschalk and Moffitt (1994). The 
variance of a variable (say, the wage rate) observed over time and for different firms can be decomposed into two separate elements: its cross-sectional dispersion at a point in time, and the (squared) deviation of the individual variable from its own average over time. ${ }^{7}$ The former - labeled "permanent" volatility - is assumed to be determined by long-run phenomena The latter - called "transitory" volatility - is assumed to be caused bytemporary shocks Since we want to test whether international exposure is associated to higher uncertainty for workers and firms, we compute such decomposition and we focus on the short-run component of volatility. ${ }^{8}$

\section{- INSERT TABLE 4 HERE -}

Table 4 shows the ratios of transitory variance over total variance for our variables in our four categories of firms. The transitory component is usually a rather small fraction of the overall variance, with a peak of 25 percent for net profits. The exporter status makes a big difference: exporters present transitory variance ratios which are systematically larger than firms not exposed to foreign competition. The difference is particularly pronounced and significant when "pure exporters" (ENFC) and "protected" firms (NENFC) are compared. ${ }^{9}$

\section{Summing up on the sample characteristics}

Our descriptive statistics suggest that globalization is not associated to significant differences in absolute and relative wages, but it is associated to significant differences in volatility of labor and product market outcomes. This is the "bad news" of globalization for (risk-averse) firms and workers. At the same time the data suggest that globalization is associated to higher training opportunities. Exporters also present faster career tracks. These are the "good news" of globalization. In the next sections we test whether this evidence withstands the scrutiny of multivariate analysis.

\section{ECONOMETRIC ANALYSIS}

In this section we test whether these results continue to hold when we condition on other characteristics of the firms. The difficulty here is that the membership to our exposed/non-

\footnotetext{
${ }^{7}$ As shown by Gottschalk and Moffitt (1994), firm i's wage rate at time $t\left(\mathrm{w}_{\mathrm{it}}\right)$ can be decomposed into the sum of two components, with $\mu_{\mathrm{i}}$ being the permanent, time invariant, component and $\mathrm{v}_{\mathrm{it}}$ the transitory component. Thus the variance of $\mathrm{w}_{\mathrm{it}}$ can then be written as the sum of the two variances $\sigma_{\mu}{ }^{2}$ and $\sigma_{\mathrm{v}}{ }^{2}$.

${ }^{8}$ Globalization brings about higher uncertainty. Yet the foreseeable, long-run component of uncertainty could be diversified away through the financial market. This is why we concentrate our attention on the short-run, presumably uninsurable, component of uncertainty.

${ }^{9}$ Lack of data does not allow the same calculation for foreign-owned and domestically owned firms.
} 
exposed categories may not be random: firms may self-select depending on observable and unobservable characteristics (such as technological, managerial and organizational efficiency) that may be the ultimate explanation for their different labor market outcomes.

In order to address this potential endogeneity bias we need to condition our estimates on an appropriate set of control variables. Although the cross-sectional nature of our data prevents us from using fully-fledged instrumental variables technique, we use proxies for managerial experience, skill and capital intensity, as well as sector and location dummies which should capture at least some of these unobservable components.

We estimate regression models for the transitory variance of labor and product market outcomes, for the probability of having training program and for the frequency of promotion and show the our main results are robust to the inclusion of a large set of controls. Next we present the results for volatility and then those for training and promotions.

\section{(i) Volatility}

We investigate whether globalization is associated with higher volatility of labor and product market outcomes. The results from OLS regressions are presented in Table 5.

- INSERT TABLE 5 HERE -

We regress the logs of the transitory variances of prices, wages, employment, sales and net profits on dummies for the EFC, ENFC, and NEFC classes, (therefore the NENFC group is the control group), as well on a dummy for FO (so that the DO category is the control group). Each regression is run in three specifications, with an increasing number of controls. The reason is that the sample size dramatically shrinks with the number of regressors, see the last column of Table 5 .

In the first specification only the class dummies appear as regressors. The results are reported in the first row of each panel. In the second specification (see the second row), we add controls for firm's sector, location, and size (this is proxied by a unionization dummy). ${ }^{10}$ Finally, in the third specification (in row 3), we add proxies for firms' productivity, such as entrepreneurial ability, capital intensity and average skill intensity. Entrepreneurial ability is measured by managerial experience (the years of experience the general manager had in the same sector before joining the firm). Capital intensity is measured as the ratio of the value of

\footnotetext{
${ }^{10}$ We have also experimented with total employment as a proxy for size, with identical results.
} 
the installed capital stock and the number of employees. Skill intensity is measured by the ratio of non-production and production workers.

This table shows a few interesting results. First, exporting firms, irrespective of whether they are subject to foreign competition in the domestic market (EFC) or not (ENFC), display a significantly higher transitory volatility than firms not subject to any foreign competition: this holds for prices, sales, employment and profits, although not for wages. In other words, exporters experience a significantly higher transitory variance of employment, product prices, sales and profits than a firm not exposed to foreign competition in any market. This effect is smaller for employment (in the interval of 6.4 and 10 per cent, based on point estimates), intermediate for product prices (between 10 and 44 per cent) and large for sales and profits (between 23.5 and 44 per cent). ${ }^{11}$

The results for the NEFC and FO dummy variables are less robust. In the baseline specification (row 1 of each panel), the coefficients of the NEFC and FO dummies are always positive and often strongly statistically significant. However, see row 2 and 3, the NEFC dummy loses significance for employment, profits and prices, once sector, location, unionization and productivity controls are included in the specification. The significance of the NEC dummy is still present for sales and wages. The foreign ownership dummy becomes stay significant only in the employment regressions when the additional controls are included.

We interpret this evidence as suggesting that globalization is positively associated with product and labor market volatility, albeit not equally for all categories of firms. The association is robust for exporting firms, but not for NEFC firms. This may be due to the measurement error induced by the subjective nature of the firm classification relative to the presence foreign competitors in the domestic market. Alternatively, the loss of statistical significance of the NEFC dummy's coefficient when controlling for productivity controls may indicate that in our sample the endogeneity problem is especially relevant for the firms competing with foreign firms in the domestic market.

\section{(ii) Training}

We test the hypothesis that firms facing foreign competition have stronger incentives to train their employees. We model the presence/absence of training as a discrete limited dependent variable, which is assumed to be distributed as a standard normal. The upper panel of Table 6

\footnotetext{
${ }^{11}$ In our semi-log equations, the effect of a dummy variable on the dependent variable is given by exp( $\left.\beta\right)-1$. E.g. in the reported examples: $6.4=\exp (2)-1$ and $44=\exp (3.8)-1$.
} 
reports the estimates (the marginal effects) of probit analysis. The unobservable indicator is assumed to depend on the foreign exposure dummies as well as other controls. The first row of Table 6 presents the estimates for the globalization dummies without additional controls. Rows 2, 3 and 4 present the results obtained adding the controls for sector, unionization, location and productivity. Row 5 shows the results when the definition of exporters is changed by lowering the required shares of exports to sales to $10 \%$ (rather than $30 \%$ ).

- INSERT TABLE 6 HERE -

The estimated coefficients of the globalization dummies are always positive and generally statistically significant, confirming that employees of firms exposed to foreign competition are more likely to be involved in training programs. Since the estimated coefficients in the relatively more parsimonious specifications (row 1, 2 and 3) may suffer from reverse causation or selection biases, the results in line 4 are our preferred ones, despite the smaller sample size. These estimates indicate that on average the probability for an EFC employee to be involved in a training program is about 30 percent higher than for a NENFC employee. We obtain similar results for the ENFC firms, although the estimated impact of "exporting only" on training is smaller and less precisely measured. The estimates for the FO dummy suggest that employees of FO firms are 40 percent more likely to receive training than employees of DO firms. . Our estimates for the NEFC dummy become insignificant when we introduce the productivity controls in the specification. This suggests that variables affecting the productivity of in NEFC firms are also important determinant of their propensity to train employees. Note that this does not seem to hold for exporting firms, no matter whether or not they face foreign competitors in the domestic market.

Overall, we interpret our findings as evidence that, the employees of exporting firms irrespective whether they are subject to foreign competition or not - are more likely to be engaged in training programs. The same applies to workers employed in FO firms. Row 5 shows that our findings are robust to changes in the definition of exporting firms.

\section{(iii) Promotions}

Next we test the conjecture that employees of globalized firms have faster careers. We look at promotion rates, defined as the share of the firm's workforce that received a promotion in 1999. This is a continuous variable ranging between zero and one. We model the promotion rate as a function of foreign competition and of the other control variables. Unfortunately, the 
data on promotions are only available for about 340 (out of 555) firms, which considerably reduces the sample size.

The OLS estimates are shown in the lower panel of Table 6 . Here we present the results for promotions along five rows - rows 6 to 10 - whose specifications exactly match the specifications in the corresponding rows in the upper panel of the table. Hence, row 6 shows results corresponding to the most parsimonious empirical specification and row 9-10 corresponding to the least parsimonious ones. As with the training estimations, the fit of the regression improves considerably when we include the location dummies. The main result from this set of regressions is that the promotion rate is about two percent higher for the average EFC employee than for the employee of the other types of firms. The statistical significance of the exporting dummy varies, however, seem to vary when we change the set of regressors and when the exports' threshold is lowered (see row 10 ).

There do not seem to be robust differences in promotion rates between other firm categories, and the (excluded) NENFC firms, as well as no differences between FO and DO firms.

Overall, the promotion results are less statistically significant than those pertaining to training of the workforce. Yet we are inclined to interpret them as (weaker) evidence that the employees of EFC firms are more frequently promoted than employees of other firms.

\section{(iv) The link between globalization and uncertainty}

Our results suggest that globalization, by raising volatility of product and labor markets (the "bad side" of globalization), enhances the incentives for training and speeds up careers, particularly for exporting firms (the "good side" of globalization). However, this interpretation is, strictly speaking, not warranted. Our results show that: (a) there exist a positive correlation between globalization and volatility and (b) there is a positive correlation between globalization, training and, promotions. Yet these correlations may not necessarily be due to the more volatile environment. For example, that correlation may be due to the fact that firms exposed to international competition need to innovate faster and invest more in human capital to stay in business.

In order to shed light on this issue, we adopt the following two-stage procedure. First, we decompose the volatility of product and labor market variables into foreign and domestic components. This is accomplished by regressing the transitory variance of each variable on the foreign competition dummies. The predicted value of such regression identifies the 
foreign component of volatility. We label the residual the "domestic" component. Second, we include the foreign component and the domestic component separately as explanatory variables in the training and promotions regressions. If globalization is directly associated to uncertainty, the coefficient of the foreign component should be "large" and significant.

\section{- INSERT TABLE 7 HERE -}

Table 7 shows that the volatility originating from foreign competition is indeed positively associated with the likelihood that firms/workers are involved in training. Looking at the training regressions we find that the estimated coefficients of foreign volatility (of prices, wages, employments, sales and profits) are all positive and highly significant (see columns 1 to 5). Moreover, the coefficients of the foreign components are typically much larger than the coefficients of the corresponding domestic component.

Columns 6 to 10 show the results for promotions. The foreign volatility of sales, prices and net profits are positively associated with promotions. Here, however, the estimated coefficients are all smaller in size.

These tests support our priors that a direct link between globalization, uncertainty and labor market outcomes is at work, particularly with respect to training opportunities. The fact that the results for promotions are less clear cut may imply that the direct and indirect effects of foreign competition on faster careers are more difficult to disentangle, and/or possibly more subject to endogeneity bias.

\section{CONCLUSIONS}

This paper provides evidence that globalization produces "twin effects". In our sample of Indian manufacturing firms, exporting, foreign-owned and, less robustly, firms subject to foreign competition in the domestic market "suffer" from higher volatility of employment, sales, profits and prices. At the same time, however, the employees of exporting and foreignowned firms are more frequently involved in training programs. Furthermore, the employees of exporting firms are more likely to be promoted. Our data support the conjecture of a "direct link" from globalization to volatility and from volatility to training. The direct link with promotion rates is instead less precisely estimated.

Our results are robust to the inclusion of various control variables, including a set of plausible determinants of firm productivity such as entrepreneurial experience, skill intensity and the capital-labor ratio, and they also hold for different - parametric and non-parametric estimation techniques (the latter are available from the authors upon request). The results 
obtained for foreign competition in the domestic market are more fragile, though, and only hold for a handful of empirical specifications.

Altogether, our analysis shows that firms exposed to globalization do not passively suffer from the new, riskier environment; they react by upgrading the skills of their labor force and, to a lesser extent, by offering faster careers to their employees. These results provide a micro-econometric foundation for the positive correlation between trade liberalization and growth often found in aggregate studies (see Dollar and Kraay, 2004), and, similarly, a new rationale for the positive correlation between exports and productivity growth at the firm level (see Bernard and Jensen, 1999).

A note of caution is required at this point. These conclusions apply to our sample of Indian firms, and whether they hold "in general" we cannot say. Moreover, these findings concern firms that survive in the globalized economy. What happens to the employees of the firms who do not, we cannot tell. Thus, from the policy side, the positive effects of globalization do not necessarily undermine the case for safety nets: these should be implemented in parallel to trade liberalization. There still is a case for promoting unemployment insurance schemes: but these schemes should be conditional upon workers' willingness to engage in training programs. 


\section{REFERENCES}

Bajpai N., Sachs J.D. and Ramiah A. "Understanding Regional Economic Growth in India", Working paper No. 88, Harvard Institute for International Development, Harvard University, 2002.

Barba Navaretti, G., M. Galeotti and A. Tucci, "Do not get trapped into crossing: Indian firms and foreign markets", Luca d'Agliano Center, 2002, mimeo.

Becker, S. and Ichino A. "Estimation of average treatment effects based on propensity scores", the Stata Journal, 2, 2002, 358-377

Bernard, A. and Jensen J.B. "Exporters, skill upgrading, and the wage gap", Journal of International Economics, 42, 1997, 3-35Bernard, A. , Stephen J. Redding and , Peter K. Schott (2006). Multi-Product Firms and Trade Liberalization, NBER Working Paper No. 12782

Bernard, A. and Jensen J.B., "Exceptional exporter performance: cause, effect or both?", Journal of International Economics, 47, 1999, 1-25.

Besley, T. and Burgess R., "Can Labor Regulation Hinder Economic Performance? Evidence from India", Quarterly Journal of Economics, 119(1), 2003.

Brown, D.K., Deardorff A.V. and Stern R.M. "The Effects of Multinational Production on Wages and Working Conditions in Developing Countries", NBER Working Paper No. 9669,2003

Cerra, V. and S. Saxena, "What caused the 1991 currency crisis in India?", IMF WP/00/157, October 2000.

Dollar, D., Iarossi G. and Mengistae T., "Investment climate and economic performance: some firm level evidence from India", Center for Research on Economic Development and Policy Reform, Working Paper \#143, May 2002.

Dollar, D. and Kraay A. "Trade, Growth, and Poverty", Economic Journal, vol. 114 (493), 2004, F22-F49.

Epifani, P. "Trade Liberalization, Firm Performance and Labor Market Outcomes in the Developing World: What Can We Learn from Micro-Level Data?", World Bank, Research Working Paper \#3067, May 2003.

Gottschalk, P. and Moffitt R. "The Growth of Earnings Instability in the US Labor Market", Brookings Papers on Economic Activity, 1994, 217-272.

Hanson, G. and Harrison A. "Who Gains from Trade Reform - Some Remaining Puzzles", Journal of Development Economics, 1999, 315-324 
Heckman, J.J., Ichimura H. and Todd P., "Matching As An Econometric Evaluation Estimator: Evidence from Evaluating a Job Training Program", Review of Economic Studies, Vol. 64(4), 1997.

International Monetary Fund (2001), "India: Recent Economic Development (2000-2001)", Washington D.C., mimeo.

Iversen, T. and Cusack, T.R. 2000, "The Causes of the Welfare State Expansion: Deindustrialization or Globalization?”, World Politics 52 (April 2000), 313-49

Manasse P. and Turrini A., "Trade, Wages and Superstars", Journal of International Economics, 54(1), 2002, 97-118.

McLaren, J. and Newman A. "Globalization and insecurity", mimeo, University of Virginia and University College, July 2002.

Ministry of Finance of India (1999a), "External Sector (1998-1999)", Government of India

Ministry of Finance of India (1999b), "Industrial Policy and Development (1998-1999)", Government of India

Robertson, R. (2000), "Trade Liberalisation and Wage Inequality: Lessons from the Mexican Experience", The World Economy, 827-849

Rodrik, D. Has Globalization Gone Too Far? Washington DC: Institute for International Economics, 1997

Rodrik, D. "Why do more open economies have bigger governments?", Journal of Political Economy, 1998, 997-1032

Slaughter, M.J. "International Trade and Labor-Demand Elasticities", Journal of International Economics, 54(1), 2001, 27-56.

Stiglitz, J. Globalization and its discontents, New York, WW Norton and Co., 2002

Suits, D.B. "Dummy Variables: Mechanics v. Interpretation", The Review of Economics and Statistics, 1984, vol. 66 (1) pp. 177-180

Topalova, P. "Trade liberalization and firm productivity: the case of India", mimeo, MIT, December 3, 2003.

World Bank. "India: Comprehensive Development Review (1998-1999)", Washington, D.C., 2000.

World Trade Organization. "India: Trade Policy Review", New York, April 1998. 
Table 1:

Firm breakdown by exposure to foreign competition and sector

Number of Firms Operating in Each Sector

\begin{tabular}{lcccccc}
\hline & Garments & Textiles & $\begin{array}{c}\text { Drugs \& } \\
\text { Pharmac. }\end{array}$ & $\begin{array}{c}\text { Electronic } \\
\text { Consumer } \\
\text { Goods }\end{array}$ & $\begin{array}{c}\text { Electrical } \\
\text { White } \\
\text { Goods }\end{array}$ & $\begin{array}{c}\text { All } \\
\text { industries }\end{array}$ \\
\hline All Sample & 178 & 159 & 142 & 44 & 32 & 555 \\
EFC & 61 & 39 & 22 & 2 & 3 & 127 \\
ENFC & 41 & 24 & 14 & 0 & 3 & 82 \\
NEFC & 28 & 36 & 49 & 20 & 17 & 150 \\
NENFC & 48 & 60 & 57 & 22 & 9 & 196 \\
$\begin{array}{l}\text { FO (Foreign } \\
\text { Owned) }\end{array}$ & 3 & 13 & 18 & 2 & 2 & 38 \\
$\begin{array}{l}\text { DO (Domestically } \\
\text { Owned) }\end{array}$ & 240 & 232 & 220 & 62 & 71 & 825 \\
\hline
\end{tabular}

Notes: EFC (Exporters and exposed to foreign competition in the domestic market) are firms with (total exports) / (total sales) $>30 \%$ and declaring to have foreign competitors in the domestic market. ENFC (Exporters and not exposed to foreign competition in the domestic market) are firms with (total exports) / (total sales) $>30 \%$ and declaring not to have foreign competitors in the domestic market. NEFC (Non exporters and exposed to foreign competition) are firms with (total exports) / (total sales) $<30 \%$ and declaring to have foreign competitors in the domestic market. $N E N F C$ are the residual category of firms not exporting and not subject to foreign competitors in the domestic market. Foreign Owned (FO) is any firm with some foreign capital ownership. Domestic Owned (DO) firms are those not included in the group of FO. 
Table 2:

Firm breakdown by exposure to foreign competition and location

Number of Firms Operating in Each Locality (States in parentheses)

\begin{tabular}{lccccc}
\hline Location & All sample & EFC & ENFC & NEFC & NENFC \\
\hline Mumbai (Maharashrtra) & 127 & 18 & 14 & 60 & 35 \\
Delhi (Haryana) & 141 & 28 & 14 & 36 & 63 \\
Chennai (Tamil Nadu) & 109 & 39 & 32 & 11 & 27 \\
Ahmedabad (Gujarat) & 22 & 5 & 2 & 5 & 10 \\
Calcutta (West Bengal) & 29 & 4 & 1 & 8 & 16 \\
Bangalore (Karnataka) & 34 & 8 & 5 & 15 & 6 \\
Hyderabad (Andhra Pradesh) & 36 & 11 & 10 & 6 & 9 \\
Kanpur (Uttar Pradesh) & 26 & 4 & 0 & 2 & 20 \\
Chandigarh (Punjab) & 13 & 5 & 1 & 4 & 3 \\
Pune (Maharashtra) & 8 & 1 & 0 & 2 & 5 \\
Cochin (Kerala) & 10 & 4 & 3 & 1 & 2 \\
\hline All localities & 555 & 127 & 82 & 150 & 196 \\
\hline
\end{tabular}


Table 3:

Labor market variables

Means for Selected Variables

\begin{tabular}{|c|c|c|c|c|c|c|c|c|}
\hline \multirow[t]{2}{*}{ Sample } & \multirow[b]{2}{*}{$\mathbf{W}_{B}$} & \multirow[b]{2}{*}{$\mathbf{W}_{W}$} & \multirow[b]{2}{*}{$\frac{W_{W}}{W_{B}}$} & \multirow[b]{2}{*}{$\frac{L_{W}}{L_{B}}$} & \multirow[b]{2}{*}{$\mathbf{L}_{T O T}$} & \multicolumn{3}{|c|}{ Unionization Training Promotions } \\
\hline & & & & & & & & \\
\hline All Sample (555) & $\begin{array}{c}38 \\
(239)\end{array}$ & $\begin{array}{l}108 \\
(239)\end{array}$ & $\begin{array}{c}7.7 \\
(239)\end{array}$ & $\begin{array}{l}.33 \\
(239)\end{array}$ & $\begin{array}{c}191 \\
(509)\end{array}$ & $\begin{array}{l}.18 \\
(496)\end{array}$ & $\begin{array}{c}.28 \\
(549)\end{array}$ & $\begin{array}{c}.02 \\
(359)\end{array}$ \\
\hline EFC (127) & $\begin{array}{c}46 \\
(71)\end{array}$ & $\begin{array}{l}257 \\
(71)\end{array}$ & $\begin{array}{l}6.5 \\
(71)\end{array}$ & $\begin{array}{l}.41 \\
(71)\end{array}$ & $\begin{array}{c}179 \\
(116)\end{array}$ & $\begin{array}{l}.14 \\
(115)\end{array}$ & $\begin{array}{l}.31 \\
(127)\end{array}$ & $\begin{array}{l}.04 \\
(67)\end{array}$ \\
\hline ENFC (82) & $\begin{array}{c}18 \\
(44)\end{array}$ & $\begin{array}{c}78 \\
(44)\end{array}$ & $\begin{array}{l}11.5 \\
(44)\end{array}$ & $\begin{array}{l}.23 \\
(44)\end{array}$ & $\begin{array}{l}286 \\
(72)\end{array}$ & $\begin{array}{l}.17 \\
(71)\end{array}$ & $\begin{array}{l}.31 \\
(80)\end{array}$ & $\begin{array}{l}.05 \\
(55)\end{array}$ \\
\hline NEFC (150) & $\begin{array}{c}41 \\
(50)\end{array}$ & $\begin{array}{l}150 \\
(50)\end{array}$ & $\begin{array}{l}7.17 \\
(50)\end{array}$ & $\begin{array}{l}.35 \\
(50)\end{array}$ & $\begin{array}{c}256 \\
(136)\end{array}$ & $\begin{array}{l}.27 \\
(132)\end{array}$ & $\begin{array}{l}.36 \\
(150)\end{array}$ & $\begin{array}{l}0.014 \\
(102)\end{array}$ \\
\hline NENFC (196) & $\begin{array}{c}46 \\
(74)\end{array}$ & $\begin{array}{l}184 \\
(74)\end{array}$ & $\begin{array}{l}7.09 \\
(74)\end{array}$ & $\begin{array}{l}.30 \\
(74)\end{array}$ & $\begin{array}{l}115 \\
(185)\end{array}$ & $\begin{array}{c}.14 \\
(178)\end{array}$ & $\begin{array}{l}.19 \\
(192)\end{array}$ & $\begin{array}{l}0.018 \\
(135)\end{array}$ \\
\hline FO (22) & $\begin{array}{c}30 \\
(11)\end{array}$ & $\begin{array}{c}70 \\
(11)\end{array}$ & $\begin{array}{l}4.09 \\
(11)\end{array}$ & $\begin{array}{l}.35 \\
(21)\end{array}$ & $\begin{array}{l}553 \\
(21)\end{array}$ & $\begin{array}{l}.51 \\
(21)\end{array}$ & $\begin{array}{l}.77 \\
(22)\end{array}$ & $\begin{array}{l}0.02 \\
(19)\end{array}$ \\
\hline DO (533) & $\begin{array}{c}40 \\
(218)\end{array}$ & $\begin{array}{l}190 \\
(218)\end{array}$ & $\begin{array}{l}8.30 \\
(224)\end{array}$ & $\begin{array}{l}.32 \\
(455)\end{array}$ & $\begin{array}{c}165 \\
(466)\end{array}$ & $\begin{array}{l}.16 \\
(454)\end{array}$ & $\begin{array}{l}.26 \\
(506)\end{array}$ & $\begin{array}{c}0.02 \\
(510)\end{array}$ \\
\hline \multicolumn{9}{|l|}{$\begin{array}{l}\text { P-values for } \\
\text { Mean Equality } \\
\text { Test: }\end{array}$} \\
\hline \multicolumn{9}{|l|}{$\begin{array}{l}\text { P-values for Mean } \\
\text { Equality Test: }\end{array}$} \\
\hline NENFC vs. ENFC & .33 & .19 & .47 & .32 & $.004^{* *}$ & .59 & $.05^{* *}$ & $.05^{* *}$ \\
\hline \multicolumn{9}{|l|}{$\begin{array}{l}\text { P-values for Mean } \\
\text { Equality Test: }\end{array}$} \\
\hline NENFC vs. NEFC & .88 & .71 & .96 & .49 & $.007^{* *}$ & $.004^{* *}$ & $.0007^{* *}$ & .57 \\
\hline $\begin{array}{c}\text { P-values for Mean } \\
\text { Equality Test: } \\
\text { FO vs. DO } \\
\end{array}$ & .44 & $.01^{* *}$ & $.02^{*}$ & .45 & $.000^{* *}$ & $.000^{* *}$ & $.0001^{* *}$ & .78 \\
\hline
\end{tabular}

Notes: ${ }^{* *}$ and ${ }^{*}$ indicate that the means calculated for the two groups of firms are significantly different, at a $5 \%$ and a $10 \%$ confidence level. $\mathrm{W}_{\mathrm{W}}=$ average hourly wages of White Collars (W); $\mathrm{W}_{\mathrm{B}}=$ average hourly wages of Blue Collars (B) in thousand rupees. Blue Collars $\left(\mathrm{L}_{\mathrm{B}}\right)=$ Unskilled Production Workers + Skilled Production and Non-Production Workers; White Collars $\left(\mathrm{L}_{\mathrm{W}}\right)=$ Managers + Professionals. "Unionization" indicates the average percentage of unionized workers for each firm category. The means reported above are computed by trimming right-end tails so as to leave out $2 \%$ of the cumulative distribution of each variable. By following this method, the following observations have been left out of the sample: $\mathrm{W}_{\mathrm{B}}>7, \mathrm{~W}_{\mathrm{W}}>20, \mathrm{~L}>5000$. "Training" is the percentage of firms that takes advantage of (in-house or external) training programs. "Promotions" measures the percentage of workers that moved to higher working positions during 1999. The number of non-missing observations for each firm group is shown in parentheses. The number of non-missing observations for each firm group is shown in parentheses. 
Table 4:

The transitory variance of wages, employment, prices, sales and net profits

Variance decomposition for Selected Variables

\begin{tabular}{lccccc}
\hline & Wages & Employment & Prices & Sales & Net Profits \\
\hline & $\sigma_{v}^{2} / \sigma^{2}$ & $\sigma_{v}^{2} / \sigma^{2}$ & $\sigma_{v}^{2} / \sigma^{2}$ & $\sigma_{v}^{2} / \sigma^{2}$ & $\sigma_{v}^{2} / \sigma^{2}$ \\
\hline $\begin{array}{l}\text { All Sample } \\
(555)\end{array}$ & .11 & .06 & .12 & .13 & .25 \\
EFC & $(400)$ & $(538)$ & $(514)$ & $(531)$ & $(487)$ \\
$(127)$ & .14 & .06 & .12 & .19 & .30 \\
$\begin{array}{l}\text { ENFC } \\
(82)\end{array}$ & $(90)$ & $(121)$ & $(116)$ & $(120)$ & $(108)$ \\
$\begin{array}{l}\text { NEFC } \\
(150)\end{array}$ & .13 & .08 & .16 & .16 & .36 \\
$\begin{array}{l}\text { NENFC } \\
(196)\end{array}$ & .10 & $(77)$ & $(78)$ & $(76)$ & $(74)$ \\
\hline $\begin{array}{l}\text { P-values for Mean } \\
\text { Equality Test: }\end{array}$ & $.112)$ & $(148)$ & .12 & .11 & .27 \\
$\quad$ NENFC vs. EFC & $.03^{* *}$ & $.143)$ & $(145)$ & $(131)$ \\
$\begin{array}{l}\text { P-values for Mean } \\
\text { Equality Test: } \\
\text { NENFC vs. ENFC }\end{array}$ & $.02^{* *}$ & .05 & .10 & .11 & .16 \\
$\begin{array}{l}\text { P-values for Mean } \\
\text { Equality Test: } \\
\text { NENFC vs. NEFC }\end{array}$ & .49 & .72 & $(177)$ & $(190)$ & $(174)$ \\
\hline
\end{tabular}

Notes: The figures in Table 4 refer to average values. $\sigma_{v}^{2}$ is the temporary component of the total variance $\sigma^{2}$. "Prices" refers to the average prices for the period 1998-99. "Wages" refers to the average nominal wage paid in the period $1997-$ 99. "Sales" refers to the average sales for the period 1997-99. "Profits" refers to the average net profits for the period 1997-99. Data computed after 2\% trimming of right-end tails. The numbers in brackets are the observations employed to compute the variable means. The asterisks ${ }^{* *}$ and ${ }^{*}$ indicate that the means of the transitory variable calculated for the two groups of firms are significantly different, at a $5 \%$ and $10 \%$. 
Table 5:

The transitory components of the variances (in logs)

\begin{tabular}{|c|c|c|c|c|c|c|c|}
\hline \multirow{2}{*}{$\begin{array}{l}\text { Dependent } \\
\text { Variable }\end{array}$} & \multicolumn{7}{|c|}{ Independent Variables } \\
\hline & $\begin{array}{c}\text { EFC } \\
\text { dummy }\end{array}$ & $\begin{array}{l}\text { ENFC } \\
\text { dummy }\end{array}$ & $\begin{array}{l}\text { NEFC } \\
\text { dummy }\end{array}$ & $\begin{array}{c}\text { FO } \\
\text { dummy }\end{array}$ & $\begin{array}{c}\text { Control } \\
\text { dummies }\end{array}$ & $\begin{array}{l}\text { Productivity } \\
\text { controls }\end{array}$ & $\begin{array}{l}\text { Number } \\
\text { of Obs. }\end{array}$ \\
\hline \multirow[t]{3}{*}{$\sigma_{v, \text { Prices }}^{2}$} & $\begin{array}{c}2.26^{* * *} \\
(.84)\end{array}$ & $\begin{array}{c}2.87^{* * *} \\
(.91)\end{array}$ & $\begin{array}{c}1.69^{* *} \\
(.79)\end{array}$ & $\begin{array}{l}2.87^{*} \\
(1.59)\end{array}$ & No & No & 437 \\
\hline & $\begin{array}{c}2.07^{* * *} \\
(.88)\end{array}$ & $\begin{array}{l}2.40^{* * *} \\
.98)\end{array}$ & $\begin{array}{l}1.30 \\
(.82)\end{array}$ & $\begin{array}{c}1.11 \\
(1.64)\end{array}$ & Yes & No & 431 \\
\hline & $\begin{array}{l}3.82^{* * *} \\
(1.20)\end{array}$ & $\begin{array}{l}3.20^{* *} \\
(1.39)\end{array}$ & $\begin{array}{c}1.04 \\
(1.10)\end{array}$ & $\begin{array}{l}-1.52 \\
(1.93)\end{array}$ & Yes & Yes & 247 \\
\hline \multirow[t]{3}{*}{$\sigma_{v, \text { Wages }}^{2}$} & $\begin{array}{l}.40 \\
(.43)\end{array}$ & $\begin{array}{l}.93^{*} \\
(.46)\end{array}$ & $\begin{array}{l}1.03^{* *} \\
(.41)\end{array}$ & $\begin{array}{l}1.30^{*} \\
(.73)\end{array}$ & No & No & 326 \\
\hline & $\begin{array}{c}.25 \\
(.46)\end{array}$ & $\begin{array}{l}.88^{*} \\
(.51)\end{array}$ & $\begin{array}{c}.70 \\
. .44)\end{array}$ & $\begin{array}{l}.68 \\
(.77)\end{array}$ & Yes & No & 322 \\
\hline & $\begin{array}{c}.88 \\
(.56)\end{array}$ & $\begin{array}{l}1.39^{* *} \\
(.63)\end{array}$ & $\begin{array}{l}.94^{*} \\
(.53)\end{array}$ & $\begin{array}{c}.28 \\
(.85)\end{array}$ & Yes & Yes & 207 \\
\hline \multirow[t]{3}{*}{$\sigma_{v, \text { Empl'nt }}^{2}$} & $\begin{array}{l}1.91^{* * *} \\
(.43)\end{array}$ & $\begin{array}{l}1.97^{* * *} \\
(.46)\end{array}$ & $\begin{array}{l}.80^{*} \\
(.42)\end{array}$ & $\begin{array}{l}2.22^{* * *} \\
(.76)\end{array}$ & No & No & 304 \\
\hline & $\begin{array}{l}1.74^{* * *} \\
(.43)\end{array}$ & $\begin{array}{l}1.86^{* * *} \\
(.47)\end{array}$ & $\begin{array}{c}.62 \\
(.42)\end{array}$ & $\begin{array}{l}1.16 \\
(.74)\end{array}$ & Yes & No & 302 \\
\hline & $\begin{array}{c}2.39^{* * *} \\
(.59)\end{array}$ & $\begin{array}{c}2.24^{* * *} \\
(.64)\end{array}$ & $\begin{array}{c}.84 \\
(.58)\end{array}$ & $\begin{array}{l}1.57^{*} \\
(.88)\end{array}$ & Yes & Yes & 187 \\
\hline \multirow[t]{3}{*}{$\sigma_{v \text {,Sales }}^{2}$} & $\begin{array}{c}3.48^{* * * *} \\
(.48)\end{array}$ & $\begin{array}{l}3.47^{* * *} \\
(.54)\end{array}$ & $\begin{array}{c}1.83^{* * *} \\
(.46)\end{array}$ & $\begin{array}{l}3.55^{* * *} \\
(.89)^{* * *}\end{array}$ & No & No & 506 \\
\hline & $\begin{array}{c}3.34^{* * *} \\
(.48)\end{array}$ & $\begin{array}{l}3.26^{* * *} \\
(.55)\end{array}$ & $\begin{array}{l}1.35^{* * *} \\
(.44)\end{array}$ & $\begin{array}{l}1.40^{*} \\
(.86)\end{array}$ & Yes & No & 494 \\
\hline & $\begin{array}{c}3.80^{* * *} \\
(.65)\end{array}$ & $\begin{array}{l}3.66^{* * *} \\
(.77)\end{array}$ & $\begin{array}{l}1.22^{* *} \\
(.60)\end{array}$ & $\begin{array}{c}1.16 \\
(1.02)\end{array}$ & Yes & Yes & 283 \\
\hline \multirow[t]{3}{*}{$\sigma_{v, \text { Profits }}^{2}$} & $\begin{array}{c}3.42^{* * *} \\
(.59)\end{array}$ & $\begin{array}{l}4.01^{* * *} \\
(.64)\end{array}$ & $\begin{array}{l}2.21^{* * *} \\
(.54)\end{array}$ & $\begin{array}{l}3.06^{* * *} \\
(1.07)\end{array}$ & No & No & 464 \\
\hline & $\begin{array}{c}3.15^{* * *} \\
(.57)\end{array}$ & $\begin{array}{l}3.68^{* * *} \\
(.64)\end{array}$ & $\begin{array}{l}1.37^{* * *} \\
(.52)\end{array}$ & $\begin{array}{c}.44 \\
(1.01)\end{array}$ & Yes & No & 459 \\
\hline & $\begin{array}{c}3.12^{* * *} \\
(.78)\end{array}$ & $\begin{array}{c}3.79^{* * *} \\
(.92)\end{array}$ & $\begin{array}{l}1.17 \\
(.73)\end{array}$ & $\begin{array}{l}.11 \\
(1.21)\end{array}$ & Yes & Yes & 268 \\
\hline
\end{tabular}

Notes: The dependent variable, for each of the five equations, is the transitory component of the variances $\left(\sigma_{\mathrm{v}}^{2}\right)$ of, respectively, prices, nominal wages, employment, sales, net profits. EFC, ENFC are NEFC are dummies for the firm's foreign exposure status $(\mathrm{E}=$ exporter; $\mathrm{FC}=$ Foreign competitors). Benchmark in each regression: non-exporter firms that are not subject to foreign competition in the domestic market (NENFC). The controls mentioned in Column 5 are unionization, sector and locality dummies, defined in the main text. The "Productivity controls" in Column 6 include the logged capitallabor ratio, entrepreneurial experience and the share of skilled production workers. Standard errors are in parentheses. *, $* *, * * *=$ coefficients significant at the $10 \%, 5 \%, 1 \%$ level of significance, respectively. 
Table 6:

The determinants of training and promotions

\begin{tabular}{|c|c|c|c|c|c|c|c|c|c|c|c|c|}
\hline \multirow[b]{2}{*}{$\begin{array}{l}\text { Dependent } \\
\text { variable }\end{array}$} & & \multirow[b]{2}{*}{$\begin{array}{l}\text { Estimation } \\
\text { methods }\end{array}$} & \multirow[b]{2}{*}{$\begin{array}{c}\text { EFC } \\
\text { dummy }\end{array}$} & \multicolumn{7}{|c|}{ Explanatory Variables } & \multirow[b]{2}{*}{$\begin{array}{c}\text { Pseudo- } \\
\mathbf{R}^{2}\end{array}$} & \multirow[b]{2}{*}{$\begin{array}{c}\text { Number } \\
\text { Obs. }\end{array}$} \\
\hline & & & & $\begin{array}{l}\text { ENFC } \\
\text { dummy }\end{array}$ & $\begin{array}{l}\text { NEFC } \\
\text { dummy }\end{array}$ & $\begin{array}{c}\text { FO } \\
\text { dummy }\end{array}$ & Unionization & $\begin{array}{c}\text { Sector } \\
\text { dummies }\end{array}$ & $\begin{array}{l}\text { Locality } \\
\text { dummies }\end{array}$ & $\begin{array}{c}\text { Productivity } \\
\text { controls }\end{array}$ & & \\
\hline \multirow{5}{*}{ Training } & (1) & Probit & $\begin{array}{l}.12^{* *} \\
(.058)\end{array}$ & $\begin{array}{c}.12^{*} \\
(.069)\end{array}$ & $\begin{array}{l}.17^{* * *} \\
(.056)\end{array}$ & $\begin{array}{l}.486^{* * *} \\
(.098)\end{array}$ & No & No & No & No & .056 & 528 \\
\hline & (2) & Probit & $\begin{array}{l}.191^{* * *} \\
(.064)\end{array}$ & $\begin{array}{l}.187^{* * *} \\
(.077)\end{array}$ & $\begin{array}{l}.10^{*} \\
(.057)\end{array}$ & $\begin{array}{l}.405^{* * *} \\
(.123)\end{array}$ & Yes & Yes & No & No & .171 & 522 \\
\hline & (3) & Probit & $\begin{array}{l}.193^{* * *} \\
(.069)\end{array}$ & $\begin{array}{l}.203^{* * *} \\
(.084)\end{array}$ & $\begin{array}{l}.140^{* *} \\
(.062)\end{array}$ & $\begin{array}{l}.320^{* *} \\
(.134)\end{array}$ & Yes & Yes & Yes & No & .240 & 522 \\
\hline & (4) & Probit & $\begin{array}{l}.30^{* * *} \\
(.098)\end{array}$ & $\begin{array}{l}.201^{*} \\
(.122)\end{array}$ & $\begin{array}{c}.062 \\
(.090)\end{array}$ & $\begin{array}{l}.40^{* *} \\
(.161)\end{array}$ & Yes & Yes & Yes & Yes & .317 & 293 \\
\hline & (5) & Probit & $\begin{array}{l}.304^{* * *} \\
(.094)\end{array}$ & $\begin{array}{l}.250^{* *} \\
(.118)\end{array}$ & $\begin{array}{l}.065 \\
(.093)\end{array}$ & $\begin{array}{l}.410^{* *} \\
(.160)\end{array}$ & Yes & Yes & Yes & Yes & .323 & 293 \\
\hline \multirow{5}{*}{$\begin{array}{c}\text { Promotion } \\
\text { opportunities }\end{array}$} & (6) & OLS & $\begin{array}{l}.020^{* *} \\
(.011)\end{array}$ & $\begin{array}{l}.031^{* * *} \\
(.011)\end{array}$ & $\begin{array}{l}-.001 \\
(.009)\end{array}$ & $\begin{array}{l}.002 \\
(.020)\end{array}$ & No & No & No & No & .022 & 344 \\
\hline & (7) & OLS & $\begin{array}{l}.018 \\
(.011)\end{array}$ & $\begin{array}{l}.030^{* *} \\
(.012)\end{array}$ & $\begin{array}{l}-.004 \\
(.010)\end{array}$ & $\begin{array}{l}-.004 \\
(.021)\end{array}$ & Yes & Yes & No & No & .023 & 342 \\
\hline & (8) & OLS & $\begin{array}{c}.012 \\
(.011)\end{array}$ & $\begin{array}{l}.023^{*} \\
(.012)\end{array}$ & $\begin{array}{l}.007 \\
(.010)\end{array}$ & $\begin{array}{l}-.000 \\
(.020)\end{array}$ & Yes & Yes & Yes & No & .102 & 342 \\
\hline & (9) & OLS & $\begin{array}{l}.025^{*} \\
(.013)\end{array}$ & $\begin{array}{l}.005 \\
(.015)\end{array}$ & $\begin{array}{l}-.002 \\
(.012)\end{array}$ & $\begin{array}{l}.020 \\
(.022)\end{array}$ & Yes & Yes & Yes & Yes & .171 & 218 \\
\hline & (10) & OLS & $\begin{array}{l}.020 \\
(.013)\end{array}$ & $\begin{array}{l}.000 \\
(.014)\end{array}$ & $\begin{array}{l}-.004 \\
(.012)\end{array}$ & $\begin{array}{l}.020 \\
(.023)\end{array}$ & Yes & Yes & Yes & Yes & .169 & 218 \\
\hline
\end{tabular}

Notes: "Training" is a dummy variable taking value one if the firm is involved in either in-house or external training programs, and zero otherwise. "Promotion opportunities" measure the number of workers promoted in 1999 divided by total employees in 1999. The benchmark in each regression is the non-exporter firm that is not subject to foreign competition in the domestic market (NENFC). The reported coefficients in rows 1 to 5 are the marginal coefficients obtained from STATA 'dprobit' procedure. In rows 5 and 10 the exporter category takes values equal to one for the firms selling more than $10 \%$ of their sales abroad and zero otherwise. In all other rows, the threshold for being exporters is $30 \%$ of total sales being sold abroad.

Pseudo- $\mathrm{R}^{2}$ values reported. Standard errors are in parentheses. ${ }^{*},{ }^{* * * *}=$ coefficients significant at the $10 \%, 5 \%, 1 \%$ level of significance, respectively 
Table 7:

Direct tests of the link between globalization and labor market outcomes

\begin{tabular}{|c|c|c|c|c|c|c|c|c|c|c|}
\hline \multirow[b]{3}{*}{$\begin{array}{l}\text { Explanatory } \\
\text { variables }\end{array}$} & \multicolumn{10}{|c|}{ Dependent variable } \\
\hline & \multicolumn{5}{|c|}{ Training } & \multicolumn{5}{|c|}{ Promotions } \\
\hline & (1) & (2) & (3) & (4) & (5) & (6) & (7) & (8) & (9) & (10) \\
\hline for $\hat{\sigma}_{v, \text { prices }}$ & $\begin{array}{l}.079^{* * *} \\
(.005)\end{array}$ & - & - & - & - & $\begin{array}{l}.0069^{* *} \\
(.0035)\end{array}$ & - & - & - & - \\
\hline $\operatorname{dom} \hat{\sigma}_{v, \text { prices }}$ & $\begin{array}{l}.005^{*} \\
(.003)\end{array}$ & - & - & - & - & $\begin{array}{c}.0004 \\
(.0059)\end{array}$ & - & - & - & - \\
\hline for $\hat{\sigma}_{v, \text { wages }}$ & - & $\begin{array}{l}.249^{* * *} \\
(.056)\end{array}$ & - & - & - & - & $\begin{array}{c}.0098 \\
(.0099)\end{array}$ & - & - & - \\
\hline dom $\hat{\sigma}_{v, \text { wages }}$ & - & $\begin{array}{l}.004 \\
(.008)\end{array}$ & - & - & - & - & $\begin{array}{l}-.0016 \\
(.0013)\end{array}$ & - & - & - \\
\hline for $\hat{\sigma}_{v, e m p l ' n t}$ & - & - & $\begin{array}{l}.145^{* * *} \\
(.032)\end{array}$ & - & - & - & - & $\begin{array}{c}.0066 \\
(.0061)\end{array}$ & - & - \\
\hline $\operatorname{dom} \hat{\sigma}_{v, \text { empl 'nt }}$ & - & - & $\begin{array}{l}.048^{* * *} \\
(.010)\end{array}$ & - & - & - & - & $\begin{array}{c}.0023 \\
(.0018)\end{array}$ & - & - \\
\hline for $\hat{\sigma}_{v, \text { sales }}$ & - & - & - & $\begin{array}{l}.068^{* * *} \\
(.013)\end{array}$ & - & - & - & - & $\begin{array}{l}.0044^{*} \\
(.0023)\end{array}$ & - \\
\hline dom $\hat{\sigma}_{v, \text { sales }}$ & - & - & - & $\begin{array}{l}.027^{* * *} \\
(.005)\end{array}$ & - & - & - & - & $\begin{array}{c}.0009 \\
(.0008) \\
\end{array}$ & - \\
\hline for $\hat{\sigma}_{v, \text { profits }}$ & - & - & - & - & $\begin{array}{l}.074^{* * *} \\
(.014)\end{array}$ & - & - & - & - & $\begin{array}{l}.0041^{*} \\
(.0023)\end{array}$ \\
\hline dom $\hat{\sigma}_{v, p r o f i t s}$ & - & - & - & - & $\begin{array}{l}.026^{* * *} \\
(.005)\end{array}$ & - & - & - & - & $\begin{array}{c}.0003 \\
(.0008)\end{array}$ \\
\hline Control dummies & Yes & Yes & Yes & Yes & Yes & Yes & Yes & Yes & Yes & Yes \\
\hline \# Observations & 450 & 335 & 308 & 518 & 472 & 290 & 235 & 206 & 341 & 313 \\
\hline $\mathrm{R}^{2}$ & .19 & .22 & .28 & .24 & .27 & .10 & .13 & .10 & .10 & .11 \\
\hline
\end{tabular}

Notes: Control dummies include sector, location and unionization dummies. Standard errors are reported in parentheses. *, $*_{* * * *}^{*}=$ coefficients significant at the $10 \%, 5 \%, 1 \%$ level of significance, respectively. 


\section{Appendix}

\section{A model of globalization, uncertainty and the firm}

Here we develop a simple model that describes the effects of uncertainty on firms' behavior. In this model, globalization raises the volatility of wages and productivity. Due to limited access to the insurance and credit market, risk-averse firms' size expands as firms try to reduce the costs of uncertainty on profits. Clearly, uncertainty may also reduce the incentives for firm specific training and promotions, for example by raising the probability of bankruptcy and lay-offs. Our model here is simply meant to illustrate a framework consistent with the facts at hand.

In a two-sector economy, the perfectly competitive (informal) sector, say agriculture, employs unskilled labor, and the manufacturing sector employs both skilled and unskilled labor. The supply of unskilled labor is perfectly elastic and there is perfect mobility across sectors, so that the real wage rate for unskilled labor is fixed at $\mathrm{w}$, the marginal value of leisure time. Unlike workers employed in agriculture, those employed in manufacturing have the option to become skilled. This requires costly training and leads, with some probability, to higher productivity and wage $(w+\Delta)$. Given the worker's optimal supply of effort, the firm chooses how many workers to employ and the optimal incentive premium $\Delta$.

In this framework, there are two sources of uncertainty. The firm faces uncertainty in profits, due to productivity shocks, $\varepsilon$. The firm chooses an incentive scheme $\Delta$ and the number of workers to employ $L$, then a productivity shock occurs, $\varepsilon \sim\left(0, \sigma_{\varepsilon}^{2}\right)$.

The representative firm chooses how many workers to employ and the optimal incentive $\Delta$, taking workers' behavior $T\left(\Delta ; \sigma_{v}{ }^{2}\right)$ into account. The productivity of each worker is stochastic and given by $(e+\varepsilon)$. Here the idea is that exposure to international competition presents opportunities and risks for firms: technological innovation may be easily adopted, fostering productivity, or may make the existing technologies obsolete, reducing productivity. Let $L$ represent the number of workers, so that employment in efficiency units is $L(e+\varepsilon)$. Output is produced according to the production function $F[L(e+\varepsilon]), F^{\prime}>0, F^{\prime \prime}<0$. Recalling that a fraction $e$ of employees is paid $(w+\Delta)$ and a fraction $(1-e)$ is paid $w$, the firms expected profits are:

$$
\begin{gathered}
\pi=E_{\varepsilon\{}\{F[L(e+\varepsilon)]-L[e(w+\Delta)+(1-e) w]\} \\
=E_{\varepsilon}\{F[L(e+\varepsilon)]-L(w+e \Delta)\}
\end{gathered}
$$


In what follows we assume for simplicity that $F(x)=x^{a}, 0<a<1$. Before the realization of the productivity shock, the firm chooses an incentive scheme $\Delta$ and employment $L$ to maximize expected profits. As above, these can be proxied by:

$$
\begin{aligned}
\pi & \cong F(e L)-[w+e \Delta] L+\left(\sigma_{\varepsilon}^{2} / 2\right) F^{\prime \prime}(e L) \\
& =F(l)-[(w / e)+\Delta] l+\left(\sigma_{\varepsilon}^{2} / 2\right) F^{\prime \prime}(l)
\end{aligned}
$$

where $l=e L$ is labor in average efficiency units. The more concave is the production function, the more the firm dislikes uncertainty. The first order condition for 1 yields: $F^{\prime}(l)+$ $\left(\sigma_{\varepsilon}^{2} / 2\right) F^{\prime \prime \prime}(l)=(w / e)+\Delta$. This expression equates the (risk corrected) marginal product of labor (in average efficiency units) to the average wage premium (always expressed in efficiency units). From this expression one can derive a labor demand function: $l=l\left(w, \Delta ; \sigma_{\varepsilon}^{2}\right)$.

It is easy to show that the volatility of productivity $\sigma_{\varepsilon}{ }^{2}$ raises the demand for labor as long as the output elasticity $a$ is less than one. Intuitively, the firm cares less about volatility the higher its revenue, so that it reacts to more uncertainty by expanding its size as measured by employment. Finally, the first order condition for the optimal incentive $\Delta$ yields: $\eta(\Delta)=$ $\left(\Delta T\left(\Delta ; \sigma_{v}{ }^{2}\right) / w\right)$, where $\eta(\Delta)=\Delta T^{\prime}() /$.$T is the elasticity of the effort function with respect to the$ wage premium. As in the standard efficiency wage model, the equality between this elasticity and the wage premium completely determines $\Delta$. Then, the training supply schedule $T\left(\Delta ; \sigma_{v}{ }^{2}\right)$ determines the optimal effort in training, while employment is determined by $l$ through the identity $L=l / e$.

Simple comparative static shows that: (a) a rise in real wage volatility $\sigma_{\mathrm{v}}{ }^{2}$ raises training effort $(e)(b)$ a rise in the volatility of productivity $\left(\sigma_{\varepsilon}^{2}\right)$ raises employment without affecting training and the wage premium (if the output elasticity $a<1$ ). 


\section{CESifo Working Paper Series}

for full list see www.cesifo-group.org/wp

(address: Poschingerstr. 5, 81679 Munich, Germany, office@cesifo.de)

3111 Johannes Metzler and Ludger Woessmann, The Impact of Teacher Subject Knowledge on Student Achievement: Evidence from Within-Teacher Within-Student Variation, June 2010

3112 Leif Danziger, Uniform and Nonuniform Staggering of Wage Contracts, July 2010

3113 Wolfgang Buchholz and Wolfgang Peters, Equity as a Prerequisite for Stable Cooperation in a Public-Good Economy - The Core Revisited, July 2010

3114 Panu Poutvaara and Olli Ropponen, School Shootings and Student Performance, July 2010

3115 John Beirne, Guglielmo Maria Caporale and Nicola Spagnolo, Liquidity Risk, Credit Risk and the Overnight Interest Rate Spread: A Stochastic Volatility Modelling Approach, July 2010

3116 M. Hashem Pesaran, Predictability of Asset Returns and the Efficient Market Hypothesis, July 2010

3117 Dorothee Crayen, Christa Hainz and Christiane Ströh de Martínez, Remittances, Banking Status and the Usage of Insurance Schemes, July 2010

3118 Eric O’N. Fisher, Heckscher-Ohlin Theory when Countries have Different Technologies, July 2010

3119 Huw Dixon and Hervé Le Bihan, Generalized Taylor and Generalized Calvo Price and Wage-Setting: Micro Evidence with Macro Implications, July 2010

3120 Laszlo Goerke and Markus Pannenberg, 'Take it or Go to Court' - The Impact of Sec. 1a of the German Protection against Dismissal Act on Severance Payments -, July 2010

3121 Robert S. Chirinko and Daniel J. Wilson, Can Lower Tax Rates be Bought? Business Rent-Seeking and Tax Competition among U.S. States, July 2010

3122 Douglas Gollin and Christian Zimmermann, Global Climate Change and the Resurgence of Tropical Disease: An Economic Approach, July 2010

3123 Francesco Daveri and Maria Laura Parisi, Experience, Innovation and Productivity Empirical Evidence from Italy's Slowdown, July 2010

3124 Carlo V. Fiorio and Massimo Florio, A Fair Price for Energy? Ownership versus Market Opening in the EU15, July 2010

3125 Frederick van der Ploeg, Natural Resources: Curse or Blessing?, July 2010 
3126 Kaisa Kotakorpi and Panu Poutvaara, Pay for Politicians and Candidate Selection: An Empirical Analysis, July 2010

3127 Jun-ichi Itaya, Makoto Okamura and Chikara Yamaguchi, Partial Tax Coordination in a Repeated Game Setting, July 2010

3128 Volker Meier and Helmut Rainer, On the Optimality of Joint Taxation for NonCooperative Couples, July 2010

3129 Ryan Oprea, Keith Henwood and Daniel Friedman, Separating the Hawks from the Doves: Evidence from Continuous Time Laboratory Games, July 2010

3130 Mari Rege and Ingeborg F. Solli, The Impact of Paternity Leave on Long-term Father Involvement, July 2010

3131 Olaf Posch, Risk Premia in General Equilibrium, July 2010

3132 John Komlos and Marek Brabec, The Trend of BMI Values by Centiles of US Adults, Birth Cohorts 1882-1986, July 2010

3133 Emin Karagözoğlu and Arno Riedl, Information, Uncertainty, and Subjective Entitlements in Bargaining, July 2010

3134 John Boyd, Gianni De Nicolò and Elena Loukoianova, Banking Crises and Crisis Dating: Theory and Evidence, July 2010

3135 Michael R. Baye, Dan Kovenock and Casper G. de Vries, The Herodotus Paradox, July 2010

3136 Martin Kolmar and Hendrik Rommeswinkel, Group Contests with Complementarities in Efforts, July 2010

3137 Carolina Manzano and Xavier Vives, Public and Private Learning from Prices, Strategic Substitutability and Complementarity, and Equilibrium Multiplicity, July 2010

3138 Axel Löffler, Gunther Schnabl and Franziska Schobert, Inflation Targeting by Debtor Central Banks in Emerging Market Economies, July 2010

3139 Yu-Fu Chen and Michael Funke, Global Warming and Extreme Events: Rethinking the Timing and Intensity of Environmental Policy, July 2010

3140 Lawrence M. Kahn, Labor Market Policy: A Comparative View on the Costs and Benefits of Labor Market Flexibility, July 2010

3141 Ben J. Heijdra, Jochen O. Mierau and Laurie S.M. Reijnders, The Tragedy of Annuitization, July 2010

3142 Erkki Koskela, Outsourcing Cost and Tax Progression under Nash Wage Bargaining with Flexible Outsourcing, July 2010 
3143 Daniel Osberghaus and Christiane Reif, Total Costs and Budgetary Effects of Adaptation to Climate Change: An Assessment for the European Union, August 2010

3144 Philip E. Graves, Benefit-Cost Analysis of Environmental Projects: A Plethora of Systematic Biases, August 2010

3145 Sabrina Di Addario and Daniela Vuri, Entrepreneurship and Market Size. The Case of Young College Graduates in Italy, August 2010

3146 Shoshana Amyra Grossbard and Alfredo Marvăo Pereira, Will Women Save more than Men? A Theoretical Model of Savings and Marriage, August 2010

3147 Jarko Fidrmuc, Time-Varying Exchange Rate Basket in China from 2005 to 2009, August 2010

3148 Ilja Neustadt and Peter Zweifel, Is the Welfare State Sustainable? Experimental Evidence on Citizens' Preferences for Redistribution, August 2010

3149 Marcus Dittrich and Andreas Knabe, Wage and Employment Effects of Non-Binding Minimum Wages, August 2010

3150 Shutao Cao, Enchuan Shao and Pedro Silos, Fixed-Term and Permanent Employment Contracts: Theory and Evidence, August 2010

3151 Ludger Woessmann, Cross-Country Evidence on Teacher Performance Pay, August 2010

3152 Lorenzo C. G. Pozzi, Casper G. de Vries and Jorn Zenhorst, World Equity Premium Based Risk Aversion Estimates, August 2010

3153 Volker Grossmann, Thomas M. Steger and Timo Trimborn, Dynamically Optimal R\&D Subsidization, August 2010

3154 Alexander Haupt, Tim Krieger and Thomas Lange, A Note on Brain Gain and Brain Drain: Permanent Migration and Education Policy, August 2010

3155 António Afonso and Christophe Rault, Long-run Determinants of Sovereign Yields, August 2010

3156 Franziska Tausch, Jan Potters and Arno Riedl, Preferences for Redistribution and Pensions. What can we Learn from Experiments?, August 2010

3157 Martin Kolmar and Andreas Wagener, Inefficient Group Organization as Optimal Adaption to Dominant Environments, August 2010

3158 Kai Carstensen, Klaus Wohlrabe and Christina Ziegler, Predictive Ability of Business Cycle Indicators under Test: A Case Study for the Euro Area Industrial Production, August 2010 
3159 Horst Rottmann and Timo Wollmershäuser, A Micro Data Approach to the Identification of Credit Crunches, August 2010

3160 Philip E. Graves, Appropriate Fiscal Policy over the Business Cycle: Proper Stimulus Policies Can Work, August 2010

3161 Michael Binder and Marcel Bluhm, On the Conditional Effects of IMF Program Participation on Output Growth, August 2010

3162 Michael Binder, Qianying Chen, and Xuan Zhang, On the Effects of Monetary Policy Shocks on Exchange Rates, August 2010

3163 Felix J. Bierbrauer, On the Optimality of Optimal Income Taxation, August 2010

3164 Nikolaus Wolf, Europe's Great Depression - Coordination Failure after the First World War, September 2010

3165 Dan Kovenock and Brian Roberson, Conflicts with Multiple Battlefields, September 2010

3166 Jean-Pierre Ponssard and Catherine Thomas, Capacity Investment under Demand Uncertainty. An Empirical Study of the US Cement Industry, 1994-2006, September 2010

3167 Jørgen Juel Andersen, Jon H. Fiva and Gisle James Natvik, Voting when the Stakes are High, September 2010

3168 Michael Hoel, Is there a Green Paradox?, September 2010

3169 Scott Alan Carson, Nineteenth Century US African-American and White Female Statures: Insight from US Prison Records, September 2010

3170 Gil S. Epstein, Yosef Mealem and Shmuel Nitzan, Political Culture and Discrimination in Contests, September 2010

3171 Sara Fisher Ellison, Jeffrey Greenbaum and Wallace P. Mullin, Diversity, Social Goods Provision, and Performance in the Firm, September 2010

3172 Silvia Dominguez-Martinez, Randolph Sloof and Ferdinand von Siemens, Monitoring your Friends, not your Foes: Strategic Ignorance and the Delegation of Real Authority, September 2010

3173 Marcus Dittrich and Beate Schirwitz, Union Membership and Employment Dynamics: A Note, September 2010

3174 Francesco Daveri, Paolo Manasse and Danila Serra, The Twin Effects of Globalization - Evidence from a Sample of Indian Manufacturing Firms, September 2010 